\title{
An Ethiopian Scholar in Tridentine Rome: Täsfa Seyon and the Birth of Orientalism
}

\author{
MATTEO SALVADORE ${ }^{*}$ and JAMES DE LORENZI* \\ E-mail: msalvadore@aus.edu; jdelorenzi@jjay.cuny.edu
}

This article surveys the diasporic life and legacy of the Ethiopian ecclesiastic Täsfa Seyon. After examining his origins in the Christian kingdom of Ethiopia and the circumstances of his arrival in mid-sixteenth-century Rome, the article outlines his contributions to the evolving Latin Catholic understanding of Ethiopia. Täsfa Șeyon was a librarian, copyist, teacher, translator, author, and community leader, as well as a prominent adviser to European humanist scholars and Church authorities concerned with orientalist philologia sacra as it pertained to Ethiopian Orthodox (täwahedo) Christianity. As such, he was a key extra-European agent in the Tridentine project of Ethiopianist and Eastern Christian knowledge production. The article also surveys the complex modern legacy of Täsfa Seyon's career, documenting his posthumous influence in the fields of Ethiopianist Semitic studies and Ethiopian vernacular historiography.

Keywords: Ethiopian diaspora, Ethiopian intellectuals, orientalism, Santo Stefano degli Abissini, Eastern churches

After the death of Pope Paul III on 10 November 1549, the Sacred College of Cardinals of the Catholic Church entered an unprecedented two-month conclave. As the faithful waited, the secluded cardinals produced sixty inconclusive ballots. Their protracted deliberations reflected the divisions within the College, which encompassed disagreements over the response to the Protestant Reformation as well as rivalries between supporters of the Holy Roman Empire and the Kingdom of France. ${ }^{1}$ After five fruitless weeks, one participant reported in his diary that on 7 January, an agitated African emerged at the balcony of the Sistine Chapel and looked down upon the assembly, exclaiming, "Very Reverend Lords, the conclavists have shut the doors, and thus now you must either starve or arrive at a decision about choosing a pope[!]"2 For some of 
the gathered princes of the Church, the outburst was surely a shock. But for the Roman Curia, the interlocutor was a familiar figure: it was abba Täsfa Seyon (1510-1553), the Ethiopian cleric also known as Pietro Abissino or Indiano. ${ }^{3}$ No interloper, he was a conclave sacrist, client of the deceased pope, and adviser to the Tridentine Catholic elite, and his proximity to Paul III was such that he attended the latter's funeral wearing the ceremonial black cloth reserved for the friends of the pontiff. ${ }^{4}$

Täsfa Seyon hailed from the tumultuous Horn of Africa. Fleeing the conflict between the Christian kingdom of Ethiopia and the Sultanate of 'Adal, he reached the Italian peninsula in the mid-1530s after a pilgrimage to the Holy Land. ${ }^{5}$ Greeted by a small diasporic community of co-religionists and other Eastern Christians in Rome, he became ensconced at Santo Stefano degli Abissini, the Ethiopian residence in the vicinity of St. Peter's Basilica. He distinguished himself through his multilingual erudition, entrepreneurial spirit, and political acumen, and ultimately became a familiar of Pope Paul III, the powerful patriarch of the Farnese family and the head of an organised Vatican effort to produce knowledge about Ethiopia and its distinctive Orthodox (täwahedo) Christian tradition. This enterprise represents the effective foundation of Ethiopian studies in Europe, a key branch of the developing field of Middle East-focused orientalist scholarship. As his intercession in the Sistine Chapel suggests, Täsfa Seyon was the most influential African in the sixteenth-century Catholic Church.

This article surveys Täsfa Șeyon's complex career and legacy in Europe and Ethiopia, emphasising his position in the intellectual networks of sixteenth-century Rome on the one hand, and his impact upon modern Ethiopianist and Ethiopian scholarship on the other. It juxtaposes a range of archival and published sources in European and Ethiopian languages. These include materials at the Vatican Library, most notably Täsfa Șeyon's own Ge ez and Latin publications, ${ }^{6}$ his marginalia in its Ge ez codices, the correspondence of his curial contacts, and the records of Santo Stefano, as well as the papal ledgers at the Archivio di Stato di Roma and the writings of his Italian collaborators. These sixteenth-century materials buttress later attestations of his significance in the overlapping fields of Ethiopianist orientalism and Ethiopian vernacular historiography. These include, in the first instance, the foundational works of the modern academic field of Ethiopia-focused Semitic studies, which drew substantially upon one of Täsfa Ṣeyon's publications, and in the second instance, the earliest outward-looking examples of modern Amharic historical writing, which re-envisioned him as an avatar of Ethiopia's place in the world.

Though this documentary record is rich, the existing scholarship is uneven. The first studies of the Ethiopian community of early modern Rome were produced by colonial-era Italian researchers keen to illustrate the historical longevity of Italo-Ethiopian relations, ${ }^{7}$ and they are marred by Eurocentric notions of diasporic Ethiopians as accidental purveyors of ancient texts or epitomes of Roman universalism. More recent works have transcended this framework. ${ }^{8}$ There are only two articles specifically focused on Täsfa Șeyon: Euringer's analysis of his epitaph, and Lefevre's essential collection of primary sources. ${ }^{9}$ These valuable but now dated preliminary studies complement more recent scholarship, which includes the concise but important sketch by 
Bausi and Fiaccadori in the Encyclopaedia Aethiopica, ${ }^{10}$ Zuurmond's close analysis of the textual features and influence of one of Täsfa Seyon's publications, ${ }^{11}$ several short discussions of this same text, ${ }^{12}$ and brief references in other works. ${ }^{13}$

The present article adds to this small literature by contending that Täsfa Seyon played a critical role in the foundation of Ethiopia-focused scholarship in Europe, and further, that his work reveals the lineal connection between the Vatican-sponsored orientalist projects of the sixteenth century, or philologia sacra, and the increasingly academic and colonial-inflected research of the modern era, or philologia orientalis. ${ }^{14}$ Recent studies have reassessed the early modern roots of orientalist scholarship, looking beyond cultural and material transactions to consider the heterogeneity and legacy of early humanist and Church-based research on Africa, East Asia, and the Levant, ${ }^{15}$ and parallel inquiries have considered the interplay between ethnology and antecedent forms of proto-ethnographic cultural description. ${ }^{16}$ Collectively, this revisionist scholarship challenges the conception of these fields as specifically modern, secular, and Enlightenment-based, as Edward Said once proposed. ${ }^{17}$ It has additionally documented the critical role of extra-European actors in the development of early orientalist studies: diasporic Asians and Africans were librarians, copyists, advisers, teachers, translators, editors, and authors of influential works, and in these myriad roles shaped or tried to shape European knowledge of their homes in highly politicised contexts. ${ }^{18}$ They met and taught their European counterparts, participated in the printing of prestige specialist works, commented on European representations of their societies and religions, intervened in interconfessional controversies, and in some cases faced intense sanctions for their views. In these respects, they were the metropolitan analogues of the broader network of imperial intermediaries who profoundly shaped the production and circulation of European knowledge about the wider world, and additionally, the early modern counterparts of the later generations of African and Asian intellectuals who contributed to and critiqued Western orientalist and anthropological research. ${ }^{19}$

Specifically, this article argues that Täsfa Șeyon was a crucial player in a Vatican effort to harness Ethiopia- and Eastern Christian-focused learning to the Tridentine project of establishing supremacy over the Protestant and Orthodox worlds. This role developed through his personal connection to Pope Paul III and Marcello Cervini, later Pope Marcellus II. Täsfa Ṣeyon was also an authoritative adviser to humanist scholars and Church authorities concerned with key areas of early orientalist inquiry, specifically the emerging scripture- and mission-related interests in Semitic languages and Eastern Christian doctrine. ${ }^{20}$ Finally, and most significantly, he was an important scholar in his own right, producing the editio princeps of the Ge'ez New Testament as well as Latin publications on the liturgy and baptismal rite of the Ethiopian Orthodox Church. These contributions endured. In the centuries after his death, his edition of the New Testament became a canonical Ge'ez source for European researchers, despite its idiosyncrasies, and it eventually underpinned the modern German historical and linguistic scholarship that is commonly viewed as the foundation of Ethiopianist Semitic studies. At the same time, his position as the head of Santo Stefano and his peerless achievements in that role made him a powerful symbol of diasporic identity for later Ethiopian and Eritrean intellectuals seeking to understand the nature of their relationship with the West. In all 
these respects, his biography illustrates the modern reverberations of an early modern connected history. ${ }^{21}$

\section{From Däbrä Libanos to the Eternal City}

Täsfa Șeyon was a steward and exemplar of the rich intellectual culture of medieval Ethiopia. In his writing, ${ }^{22}$ he introduced himself as an alumnus of Däbrä Libanos monastery, a leading centre of Orthodox Christian learning in the Ethiopian highlands. ${ }^{23}$ Founded in the fourteenth century by abunä Täklä Haymanot, Däbrä Libanos played a major role in the religious and political life of the kingdom, and its abbot, the eç̣çägé, was the highest ranking domestic ecclesiastic in the Ethiopian Orthodox Church, subordinate only to the Coptic metropolitan. When Täsfa Șeyon entered the monastery in the early sixteenth century, it was led by the erudite eç̣çägé 'Enbaqom, a Yemeni-Ethiopian convert to Orthodox Christianity who would later advise Emperor Gälawdéwos. ${ }^{24}$ Together, the abbot and brethren presided over a period of Ge'ez literary efflorescence which encompassed the standardisation of the hagiography ( $g \ddot{a} d l$ ) of Täklä Haymanot, ${ }^{25}$ the preparation of original exegetic works like the anti-Islamic treatise Anqüsä amin ${ }^{26}$ and the translation of Arabic Christian literature, such as the commentary of St. John Chrysostom, the computational treatise of Abū Šākir b. Abī 1-Karam Butrus b. al-Muhaddib, the pseudo-Buddhist epic of Baralaam and Josaphat, and the universal history of Ğirğis al-Makīn b. al- Amīd. ${ }^{27}$ As a young initiate, Täsfa Șeyon witnessed or contributed to this project of intercultural textual transmission, which transformed the canon of Ethiopian church scholarship, and in his later years, he invoked eç̣çägé 'Enbaqom in his own work and adopted the monastic title malhezo, both suggestions of his elevated position at the monastery. ${ }^{28}$

Däbrä Libanos eventually led him to the institutions of secular power. ${ }^{29}$ In a letter to one of his Roman collaborators, Täsfa Șeyon identified himself as "the secretary [ṣähafé] of Așnaf Sägäd," the regnal name of Emperor Gälawdéwos, and he told another European colleague that he had taught the Portuguese representative Pêro da Covilhã "many things of the world" in the court of Emperor Lebnä Dengel, the father of Gälawdéwos. ${ }^{30}$ These statements suggest that Täsfa Seyon served the royal family in an administrative role, possibly as a scribe or annalist subordinate to the court historian (sähafé te'ezaz), a position ultimately assumed by his monastic superior eç̣çägé 'Enbaqom. ${ }^{31}$ Since Täsfa Șeyon left Ethiopia before the accession of Gälawdéwos in 1540, he was likely attached to the court during the prior reign of Lebnä Dengel, when the heir was a minor. Such a connection is suggested by the royal chronicle of Gälawdéwos, which describes the latter's rigorous childhood church education, and additionally by the precedent of the anonymous chronicler of Emperor Bä' edä Maryam, who served the royal family as a preceptor and inter-generational dynastic annalist. ${ }^{32}$ Täsfa Seyon was thus part of the intellectual elite who adorned royal power.

This role placed him in a precarious position during an era of religious strife. In 1532, as wars raged between local Muslims and Christians and their Ottoman and Portuguese allies, the army of Aḥmad b. Ibrāhīm al-Ġāzì destroyed Däbrä Libanos and its 
scriptorium. ${ }^{33}$ It was for this reason that Täsfa Șeyon later called him "the poisoning one," or maśarri. ${ }^{34}$ As the forces of Lebnä Dengel battled the 'Adal invaders, several of Täsfa Seyon's monastic brethren made the pilgrimage to Egypt and the Holy Land, and he followed their example in the 1530s, possibly because of the destruction of Däbrä Libanos. After the subsequent martyrdom of its abbot eç̣çägé Yohannes, ${ }^{35}$ the monastery was abandoned by the Church for 160 years. ${ }^{36}$ Even centuries later, its literary achievements in the sixteenth century and the calamity of its destruction weighed upon the Christian faithful. ${ }^{37}$

From Jerusalem, Täsfa Șeyon next made the pilgrimage to Rome. He may have done so with some knowledge of the Ethiopian community at Santo Stefano, which was available at Emperor Lebnä Dengel's court from either resident Europeans or returned Ethiopian pilgrims. ${ }^{38}$ One of four church-cum-hospice structures owned by the Chapter of St. Peter, Santo Stefano had long hosted clerics serving in St. Peter's Basilica, and by the late fifteenth century, a fluctuating number of Ethiopians resided there, against the will of the title holder. ${ }^{39}$ When Täsfa Șeyon arrived decades later, it was incontrovertibly associated with the Ethiopian community: the Romans renamed it Santo Stefano dei Mori or Santo Stefano degli Indiani, while the Ethiopians christened it Däbrä Qeddus Esțifanos, employing the Ge'ez monastic nomenclature to refer to their adopted residence as "the Mount of Saint Stephen." 40

Some Ethiopians made the complex a permanent home, while others stopped briefly en route to more distant religious shrines. For this reason, the size of the community at Santo Stefano fluctuated considerably: between the 1510s and 1530s, the number of residents was reportedly between six and thirty-eight, and when Täsfa Șeyon arrived in the mid-1530s, it was home to a dozen pilgrims. ${ }^{41}$ But despite its small size, Santo Stefano was probably the best-known community of free Africans in early modern Europe. Its residents were noticed by Muhammad al-Wazzān al-Fāsī, better known as Leo Africanus, who lived in Rome in the 1520s and wrote in his "Della descrittione dell'Africa" (1550) of "certain religious who are friars and have their faces branded; they can be seen throughout Europe but especially in Rome." ${ }^{42}$ As this comment suggests, Santo Stefano had become one of many Roman spaces associated with a specific stranger population, exemplifying the cosmopolitanism produced by the city's emergence as a multiethnic pilgrim centre. ${ }^{43}$

\section{The Tangled Roots of Ethiopianist Knowledge}

Täsfa Șeyon arrived at a favourable juncture in Ethiopian-European relations. Medieval European interest in Ethiopia derived from the Latin quest for the mythic Christian sovereign named Prester John. Initially associated with Asia, Prester John was by the fourteenth and fifteenth centuries linked to northeast Africa. This discursive metamorphosis reflected two intertwined trends: the increased reporting of traders and missionaries in the East, who refuted the notion of a Christian potentate in Asia; and the trickle of Ethiopian pilgrims and diplomatic emissaries to the Italian and Iberian peninsulas, who 
claimed they hailed from a powerful but beleaguered Christian empire, obliquely accepting the identification with the fabled sovereign. This association afforded Ethiopians hospitality as pilgrims and value as informants, improving their inherently vulnerable position as strangers, and by the late fourteenth century, their contacts with Latin scholars eager for information about the region began to directly shape the European conception of Africa. ${ }^{44}$ This Ethiopian engagement with Europe coincided with the escalating European interest in the non-Western world.

The new brokered understanding of Ethiopia first emerged in Venice. The vast commercial network of the port city made it a natural hub for the dissemination of knowledge about the wider world, and its links with the Eastern Mediterranean facilitated the arrival of Ethiopian pilgrims from Egypt, Crete, and the Holy Land. In 1402, the first documented Ethiopian embassy reached Latin Europe, and this undertaking produced the Iter de Venetiis ad Indiam, an anonymous itinerary describing the route from the lagoon to Prester John's kingdom, complemented by an Amharic-Italian lexicon, the first such work for an Ethiopian Semitic language. ${ }^{45}$ In the 1440s, the mapmaker Fra Mauro Camaldolese produced his famous Mappamundi, whose impressively accurate rendering of the Horn of Africa he attributed to the testimony of "those who grew up here, who are prelates." 46 A few decades later, Alessandro Zorzi produced an extra-European geographic compendium, which included multiple itineraries linking Ethiopia to Cairo and Jerusalem obtained from Ethiopian visitors to the Republic. ${ }^{47}$ These Venetian projects complemented the products of other hubs of protean Ethiopianist knowledge, most notably Florence and Naples. When taken together, they represent fragmentary contributions to an emerging Ethiopianist library, the first corpus of European works dedicated to an African society south of the Sahara. ${ }^{48}$

This preliminary phase of Ethiopianist knowledge production derived from chance and personal initiative. In nearly every case, well-positioned European geographers interested in the wider world seized the opportunity to acquire rare information from itinerant Ethiopians. By the early sixteenth century, however, European interest in Ethiopia began to transcend such geographic curiosity through the emerging field of philologia sacra, which looked beyond Hebrew to the Semitic languages of Eastern Christianity in order to more deeply elucidate the scriptures. ${ }^{49}$ This shift towards a distinct field of European oriental studies is exemplified by the 1513 edition of the Ethiopian Psalter, which contains the Ge'ez version of the Book of Psalms, and which represents the first printed text in an African language, predating an Arabic edition of the Book of Hours by one year. ${ }^{50}$ The Psalter's publisher was Johannes Potken of Cologne, a papal secretary in the Roman Curia who developed an interest in Ge'ez, which he tendentiously identified as Chaldean. ${ }^{51}$ This led him to the Ethiopians of Santo Stefano, where he studied the language with a resident named Tomas Wäldä Samu 'él. Using a manuscript delivered by a fifteenth-century Ethiopian delegation, the two collaborated on an edition of Mäzmurä dawit, or the Ge ez Psalms, ${ }^{52}$ printed by the prominent Silber brothers. ${ }^{53}$

This was a watershed achievement. Most notably, the work contained the first printed autobiographical statement by an African author. In an interpolated leaf featuring red and black ink, a Ge'ez text announced: 
This Psalter [dawit] was printed in the city of Rome by Johannes Potken, German and elder [prépositos] of the Church of Saint George of the city of Cologne of Germany, and with him, I Tomas Wäldä Samu él, monk [gädamawi] and pilgrim of Jerusalem, on the seventh of the month of Hamlé, the year of our Lord Jesus Christ, son of God and the Virgin Mary, 1513 Amen. ${ }^{54}$

This statement suggests several important developments. Before this collaboration, Ethiopians acted as informants for European interlocutors who limited themselves to presenting corrupted fragments of mediated Ethiopian knowledge. The production of the Psalter, in contrast, required an intensive and sustained investment of time and resources, and a substantial partnership between a European, who could navigate the institutional side of the printing process, and an Ethiopian, who could prepare a reliable text, review the type and proofs, and provide a suitable contextual apparatus. This last point is a littlenoticed but highly significant feature of the Psalter as an example of linguistic scholarship: its first pages contain an introduction to the Ethiopic script ( fidäl), the ha-hu sequence, and $\mathrm{Ge}^{\prime} \mathrm{ez}$ pronunciation as well as grammar. As these contextual materials, their intended European reader, and the larger project suggest, Tomas Wäldä Samu 'él exemplified a new role for Ethiopians in their intellectual interactions with Europeans: he was not a purveyor of information but an intellectual agent with a clearly articulated authorial identity, and a direct participant in the unfolding print revolution and developing field of Eastern Christian-focused research.

The publication of the Psalter coincided with a diplomatic development that similarly transformed European knowledge of Ethiopia. In 1514, the Armenian-Ethiopian ambassador Matéwos arrived in Lisbon and persuaded the Crown to dispatch a mission to Emperor Lebnä Dengel, which departed the following year. A flood of publications celebrating the discovery of the realm of Prester John followed, adding reports of current events in Ethiopia to the comparatively scholarly works discussed above. In 1516 and 1518, Andrea Corsali, the papal representative in the Portuguese delegation, sent two letters to Rome that were printed and widely circulated, ${ }^{55}$ and in 1520 , the governor and auditor general of the Estado da Índia dispatched two letters to Lisbon announcing contact with representatives of the Ethiopian ruler, which were promptly printed. ${ }^{56}$ The following year, King Manuel I published a pamphlet announcing the Portuguese discovery of Prester John, ${ }^{57}$ and in 1532, after the Portuguese legation returned to Lisbon, the courtier and Ethiopia-enthusiast Damião de Góis published a short account of Matéwos's visit almost two decades prior. ${ }^{58}$ In the decades immediately following the groundbreaking Psalter and the mission of Matéwos, the Latin Catholic elite displayed clear symptoms of Prestermania.

\section{Täsfa Șeyon, the World Historian, and the Spirituale}

It was in this changing political and intellectual context that Täsfa Șeyon reached the eternal city. Whether because of his erudition or familiarity with the role of the scholarly adviser of the powerful, his earlier career in the Ethiopian highlands prepared him to look beyond the diasporic confines of Santo Stefano. Within a few years, Täsfa Șeyon became 
a critical intermediary in the arena of Ethiopian-European relations and the related institutionalisation of Ethiopia-focused knowledge production. For the Curia and the small community of Catholic orientalists focused on understanding the languages and texts of Eastern Christianity, Täsfa Șeyon was the resident Roman authority on Ethiopia, Ethiopian Orthodox Christianity, and the real Prester John.

This new role began with his intervention in the case of João Bermudes, the former barber-bleeder of the Portuguese mission to Emperor Lebnä Dengel. As the Jesuit Alfonso Salmeron later told Ignatius Loyola,

\begin{abstract}
A Portuguese man [Bermudes] had come from Prester John's India in the company of two [Ethiopian] emissaries who brought letters from the prince for the pope. It seems that one of the emissaries died on the journey here and the other one died near Venice; and so, the Portuguese man brought the letters to Rome, for the pope. Friar Pedro [Täsfa Șeyon], who is from there, was asked to read them. ${ }^{59}$
\end{abstract}

In Rome, Bermudes told an astonishing tale. He had remained in the war-torn highlands until the mid-1530s, when the emperor returned him to Europe to obtain military support for the Christian kingdom. However, unbeknownst to Lebnä Dengel, Bermudes covertly expanded this mandate: once in Rome, he claimed that abunä Marqos, the dying metropolitan, had named him as his ecclesiastic successor. ${ }^{60}$ This was preposterous on several levels: Bermudes not only lacked suitable qualifications, but the Ethiopian Church had since its inception been headed by a Coptic bishop appointed by the Patriarch of Alexandria in consultation with the residents of the monastery of Saint Anthony, and this metropolitan of Ethiopia, or abun, had never named his own successor.

Bermudes's arrival led to the summoning of Täsfa Seyon, who was tasked with translating his letters. Given the latter's unique qualifications, he was likely additionally asked to assess the claims of Bermudes and explain the workings of the Ethiopian Orthodox Church, then obscure to Europeans. As a learned scholar from an Ethiopian monastery and an alumnus of the royal court, Täsfa Șeyon would have found it easy to persuade a likely already sceptical Curia to reject the barber-bleeder's bid for ecclesiastical power - though Bermudes later boasted that Paul III appointed him not only abun of Ethiopia but also "Patriarch and Pontifex" of Alexandria ${ }^{61}$ In reality, his aggrandising claim was rejected by the Vatican - to say nothing of the Ethiopian Church. This outcome suggests that Täsfa Șeyon helped expose a prominent fraud, thereby becoming the resident Vatican expert on Ethiopia.

This new role was exemplified by Täsfa Seyon's subsequent collaboration with two Italian scholars caught up in the Prestermania: the learned prelates Paolo Giovio and Ludovico Beccadelli. The two probably developed their interest in the region through their involvement in the 1532-33 papal consistory in Bologna, when Pope Clement received Francisco Álvares, chaplain of the Portuguese mission to Ethiopia. ${ }^{62}$ Álvares claimed to have received the emperor's pledge of obedience to Rome, and offered as proof the first letters from an Ethiopian ruler to the pontiff, ostensibly confirming the fealty of the long-sought Prester John. In an era of Protestant challenge, the declaration epitomised the legitimacy and universality sought by the embattled papacy, ${ }^{63}$ and the 
sensational event was publicised through a widely circulated pamphlet titled Legatio David Aethiopiae Regis, reprinted in multiple languages. ${ }^{64}$

Giovio seems to have contributed to this anonymous publication. Its introductory essay claimed he had translated the correspondence and was additionally planning to translate a Portuguese manuscript Álvares had brought to Bologna. ${ }^{65}$ This was in all likelihood a copy of the latter's famous travel narrative, which was published in Portugal in 1540 as Verdadeira informação das terras do Preste João das Indias. ${ }^{66}$ It was the first European eyewitness account of the assumed Prester John and one of the earliest protoethnographic descriptions of the societies of the Horn, the complement of the ethnogeographic manuals that aided European expeditions in the wider Indian Ocean arena. ${ }^{67}$ It circulated widely after 1559 through its inclusion in the first volume of Giovanni Battista Ramusio's influential Delle navigationi et viaggi, which also included Corsali's letters and the royal epistles from the Legatio. ${ }^{68}$

Although Giovio never actually translated the manuscript, he continued to develop his interest in Ethiopia. After joining the Curia and becoming a close adviser of Pope Clement, he was privy to current overseas intelligence, including reports about the slow progress of the Portuguese mission, as well as the reserve of Ethiopian knowledge at Santo Stefano. This privileged position led him to contact Täsfa Șeyon, whose testimony eventually informed a Prester-inflected historiographical fusion of medieval fantasy and the latest cutting-edge Ethiopian scholarship. ${ }^{69}$ In his magnum opus, Historiarum sui temporis (1550), Giovio offered a brief "Description of Africa" that mixed conventional accounts of troglodytes and other physiognomic oddities with a nuanced discussion of Ethiopia and its recent history. ${ }^{70}$ Giovio explained that the latter derived from Álvares and "Pietro Abissino, man of illustrious and honourable ingenuity, [who] with great humanity and faithfulness told me the notable things about Abyssinians." ${ }^{, 71}$ Either informant could have shaped Giovio's descriptions of topics such as Emperor Lebnä Dengel's life and daily routine, but only Täsfa Șeyon could have provided the prelate with such a convincingly laudatory overview of his homeland of Šäwa, on the basis of which Giovio boldly asserted that the Šäwans "preceded all Abyssinians in astuteness, ingenuity, sobriety, customs and good-living," and "rule no different than Venetian gentlemen!"72

Giovio's accumulative Ethiopian pastiche and panoptic historiographical fusion of European and non-European knowledge exemplify a larger sixteenth-century shift from universal to world historiography. ${ }^{73}$ At a time when most local historians wrote dynastic histories based on archival sources and official chronicles, and when universal historians conceptualised world history from the perspective of an outward-looking home society, Giovio instead exploited Rome's emerging role as a cosmopolitan crossroads to synthesise and aggregate the testimonies of foreign visitors and the products of the expanding Vatican information network. Yet this distinctive historical method also set Giovio apart from the growing number of sixteenth-century orientalists whose principal concern was the mastery of Semitic languages in order to deepen scriptural understanding. In contrast to the latter, Giovio purported to be motivated by a more worldly simple curiosity, adding that he described Ethiopia so as to distract readers from "so many 
bloody wars and sad events. ${ }^{.74}$ In short, if his study in many respects typified the innovative world historiography of the era, his references to medieval lore about Ethiopia and Africa failed to account for the most recent reports from the Horn as well as the developing European understanding of Eastern Christian traditions.

In this, he differed from his contemporary Beccadelli. A Bolognese erudite famed for his literary accomplishments and remarkable ecclesiastical career, Beccadelli joined Giovio at the Bologna hearing as secretary to Cardinal Gasparo Contarini. The latter was a leading member of the spirituali, a circle of lay and ordained figures committed to humanism, ecumenism, and church reform, and whose broad intellectual interests and personal quest for transcendence and salvation have led to their characterisation as a "religious republic of letters." 75 The spirituali critiqued the state of the Church and sought accommodation with the Protestants, and this drew some of them towards the concept of union with Eastern Christianity. ${ }^{76}$ They were opposed by the zelanti, who rejected such accommodation and championed strict Catholic orthodoxy. For his part, Contarini saw Eastern Christianity as a model for Protestant reconciliation, and shortly before his death, this question led him to summon $a b b a$ Yohannes, an Ethiopian cleric then residing in Venice. ${ }^{77}$ While the motives for this invitation are unclear, they can plausibly be interpreted as a reflection of Contarini's favourable orientation towards Orthodox Christianity.

It was through Contarini that Beccadelli was introduced to the spirituali and their ecumenism. In 1539, Beccadelli's interest in Ethiopia crystallised when he acquired an anonymous and reportedly disorganised Italian version of Álvares's narrative, most likely an unpublished translation of the manuscript the recently deceased chaplain had brought from Bologna to Rome. Armed with this source, Beccadelli completed an improved version of Álvares's work in 1542, two years after the Portuguese edition appeared. In its dedication, he explained:

[I] ordered, divided, and made it as much clear as I could, only by adding a few things in certain places, where our Ethiopians in Rome disagree with what is written. Because you must know that to be faithful to the truth and my satisfaction, I confirmed it with our good Ethiopian, fra Pietro [abba Täsfa Șeyon], and others of his [Ethiopians]. ${ }^{78}$

These consultations with Täsfa Șeyon and the other residents of Santo Stefano resulted in forty-two "additions" of original commentary on Álvares's text. ${ }^{79}$ This was an innovation: if Giovio somewhat haphazardly fused ancient and modern accounts in a grand historical survey, Beccadelli instead edited a cutting-edge eyewitness account of Ethiopia, rich with historical and proto-ethnographic observations which he vetted and complemented through interviews with diasporic Ethiopians. This was a specialist work fusing travel narrative and scholarship. Yet at its core, Beccadelli's Ramusio-esque re-edition and elaboration of Álvares's work reflected the era's contentious religious politics. His consultations with Täsfa Șeyon and his colleagues clarified aspects of Ethiopian Orthodox doctrine and practice deemed troubling by the Vatican, and his revisions sought to preempt and assuage critics of Ethiopian Christianity amid the era's increasing conservatism. ${ }^{80}$ 
Most notably, his research led him to dismiss the theological relevance of Ethiopian practices such as annual baptism, which he explained was performed not as a sacrament but simply "to commemorate the baptism of Christ." As for the practices of scarification and tattooing, Beccadelli related that the monks explained "they were done to improve the eyesight, for different traditions, and for beauty," and that "brother Pietro [Täsfa S.eyon] said that they are done. . . to distinguish themselves from other tribes, as much of Ethiopia regards as enemies those ancient Jews who came to Ethiopia with the son of Solomon [Menilek I].” Beccadelli also reported several details about Däbrä Libanos likely derived from Täsfa Șeyon, including the fact that "the mother of Prester John" had entered it as a nun. ${ }^{81}$ Given Täsfa Seyon's proximity to the Vatican and awareness of its ongoing politico-doctrinal struggles, one can only speculate if his dialogue with the prelate aimed to subtly influence the shifting currents of the day with respect to Ethiopian Christianity and ecumenical politics. What is more certain is that Beccadelli framed his discussion to preempt accusations of Ethiopian heresy, and that his work and the broader spirituali anxiety about the nature of Eastern Christianity anticipated future Catholic debates about the nature of Asian religions that appeared to predate the Abrahamic traditions. ${ }^{82}$

\section{Ethiopia and Tridentine Orientalism}

In the aftermath of the Portuguese delegation's return from Ethiopia in 1527, the European discourse on Prester John and Ethiopian Christianity mutated: ecumenism and celebration yielded to scepticism and intransigence. This transformation reflected two parallel but distinct developments: Ethiopia's manifest geopolitical weakness and the growing doctrinal intolerance of the Latin Catholic world. The Portuguese missions to Ethiopia revealed a beleaguered kingdom on the brink of defeat and in dire need of military aid: Emperor Lebnä Dengel seemed the antithesis of the mighty Prester John, and his successor Emperor Gälawdéwos fared only slightly better. After Christóvão da Gama, son of the famed explorer and leader of the Portuguese military expedition sent to support the failing monarchy, was captured and executed by the forces of 'Adal in 1542, the combined Ethiopian-Portuguese forces regrouped and managed to defeat and repel the invaders and their Ottoman allies from the highlands. However, the surviving Christian kingdom bore little resemblance to either its former self or the mythic European ideal. Despite the Prestermania of the day, it was clear to Portuguese authorities that the Ethiopian reality defied expectations.

As Christian Ethiopia confronted one existential threat, Rome grappled with another: the Protestant Reformation. In 1541, Contarini tarnished his reputation through his failed efforts towards reconciliation at Regensburg, and the following year, Paul III acquiesced to the zelanti and established the Roman Inquisition, placing at its helm their unyielding ringleader Cardinal Gian Pietro Carafa, the future Pope Paul IV. This institutionalised intolerance transformed the Church's official position on Eastern Christianity and Ethiopian Orthodoxy in particular, a shift that had been apparent in Portugal since the 
late 1520s. If in Rome the authorities fixated on the Protestants, in Portugal the anxiety focused on the New Christians. The community of conversos grew considerably after the immigration of expelled Spanish Jews (1492) and the ensuing Portuguese policy of forced conversion (1496), and the messianic pretensions of David Reubeni in the 1520 s excited a Jewish revival that vexed Christian authorities. ${ }^{83}$

This charged context awaited the Ethiopian ambassador Șägga Zä'ab, who reached Lisbon in 1527 with the returning Portuguese delegation. An Italian-speaking monk and former liqä kahenat, or arch-priest, Șägga Zä'ab found a hostile Portuguese court. He was interrogated by its clerics, accused of Judaic heresy, and denied the possibility of completing what he claimed was his-and not Álvares's-mission to meet the pontiff on behalf of Emperor Lebnä Dengel. ${ }^{84}$ Ṣägga Zä'ab eventually departed with Bermudes in the mission to relieve the emperor, and tellingly, Cardinal Afonso entrusted the Portuguese fabulist with a stern letter asking Lebnä Dengel to renounce heresy and "to conform to the Holy Church and to obey, in all things, the Catholic faith." ${ }^{.85}$

As this missive suggests, and as Beccadelli was then realising, the growing awareness that Ethiopia defied Latin Catholic expectations had implications for the production of Ethiopianist knowledge. Unlike the societies of the New World and Asia, highland Ethiopia had at least initially seemed to possess a superficial resemblance to European Christendom, with an integrated church and state, a highly developed monastic culture and scribal tradition, and a poorly understood but lineally adjacent Eastern Christian faith. But the increasing contact and concomitant European understanding of Ethiopian doctrine revealed a far messier reality, and the latter's significance became an arena of charged scholarly disputation.

This point was obvious to Șägga Zä'ab. Trapped at court, he befriended the scholar Damião de Góis, who helped him smuggle and publish in Louvain his 1540 confession of faith, the scandalous Fides, Religio Moresque aethiopum. ${ }^{86}$ Circulating widely in many editions, it offered European readers the first detailed account of Ethiopian Orthodox doctrine and the Ethiopian narrative of the Queen of Sheba, the Kebrä nägäst , and additionally advanced a defence of the Ethiopian church and scathing critique of its Catholic counterpart. These sensational topics captivated Góis's mentor Erasmus of Rotterdam, who upon learning about Șägga Zä’ab's claims from his student, discussed them in his Ecclesiastes. ${ }^{87}$ Portugal's Grand Inquisitor Cardinal Henrique eventually censored the Fides, ${ }^{88}$ and in the ensuing decades, Góis was repeatedly denounced to the Inquisition and eventually sentenced to monastic confinement. ${ }^{89}$ In Rome, meanwhile, Beccadelli's re-edition of the Álvares manuscript stalled and was never printed, most likely because of his inquisitorial fears. As these contemporaneous episodes suggest, the production of Ethiopianist knowledge now faced close oversight. If Góis and Beccadelli had used their scholarship and connections to Șägga Zä'ab and Täsfa Seyon to accommodate Ethiopian Christianity to their ecumenical vision, the intervening politico-religious developments in Europe and the Horn produced an outpouring of Tridentine Ethiopianist orientalist scholarship that was more overtly instrumental.

The career of the prelate Marcello Cervini exemplifies this development. His rapid ecclesiastical ascent began as a client of the Farnese clan: after the elevation of 
Alessandro Farnese as Paul III in 1534 and his own ordination the following year, Cervini held several influential positions in the Curia, including papal secretary and legato a latere to the imperial court. Upon his elevation to the office of cardinal in 1539, he assumed a crucial role in the ongoing negotiations with the Protestant world, and after Contarini's failure at Regensburg, he became a chief architect of the Council of Trent (1545-1563). In 1546, he joined the board of directors of the Roman Inquisition, and finally, in 1555 he briefly ascended to the papacy as Marcellus II.

While pursuing this glittering Church career, Cervini cultivated his scholarly interests through editions of classical and patristic texts. ${ }^{90}$ This pursuit led him to become a benefactor of the Vatican Library, of which he would become the first cardinal protector in 1548, and he was additionally a key agent in the revitalisation of the Roman printing industry. His parallel and somewhat contradictory roles as an influential proponent of Counter-Reformation Catholicism, on the one hand, and an unwavering humanist on the other, have generated controversy with respect to his position in the spirituali-zelanti struggle. ${ }^{91}$ Adding to this complexity is the recent argument that his bibliophilic activities and interest in Eastern Christianity qualify him as an orientalist. ${ }^{92}$ This characterisation is apt: though not an author himself, Cervini pursued and sponsored language- and textbased - as opposed to observed or reported - knowledge of Eastern Christianity and actively shaped the parameters of its production, and more specifically, he saw Ethiopianist scholarship as a useful intellectual weapon in the unfolding politico-religious showdown with the Protestants. For these reasons, however, it is also simplistic to suggest he was a "good and kind father of the Orient."93

Cervini's instrumentalisation of Ethiopia-focused scholarship developed in the 1540s, during his work at the Council of Trent. In an attempt to aid the Counter-Reformation agenda, the Cardinal paused his humanist intellectual and bibliophilic projects and redirected his attention and capital towards endeavours germane to his immediate political aims. Despite his long-standing interest in canonical classical texts, his first two sponsored publications were defences of papal authority: the letters of Nicholas I (1542) and Innocent III (1543), and Henry VIII's Defense of the Seven Sacraments (1543). ${ }^{94}$ He next pursued the acquisition, study, and publication of Eastern Christian texts that could buttress his defence of papal supremacy at the Council, and to this undertaking he rallied Latin orientalists as well as the learned Eastern Christian diaspora in Rome. In the mid-1540s, Cervini supported the Syriac Orthodox deacon Petrus of Damascus during his sojourn in Rome, and eventually sent him to the German scholar Johann Widmannstetter to serve as an Arabic translator. In the late 1540s, Cervini likewise sponsored Petrus's coreligionist Moses of Mardin, and invested in the possibility of printing the Syriac New Testament. ${ }^{95}$ These contacts developed in the context of the question of Catholic communion with Maronite and Syriac Orthodox Christians and the perceived utility of such a relationship to the Vatican as a model of interdenominational fraternity.

It was against this backdrop that Cervini enlisted Täsfa Seyon in his effort to strategically deploy Eastern Christian learning. The Cardinal's correspondence from Trent with his collaborators in Rome documents the connection. In one 1546 letter, Guglielmo Sirleto, the custodian of the Vatican Library, informed Cervini that Täsfa Ṣeyon had 
acquired and would translate a Ge ez manuscript containing the Nicene canons, which included "eighty-four [canons] beyond the twenty we already had," one of which, Sirleto reported, "speaks of the primacy of the Roman Church above any other." 6 Although we lack Cervini's reply, his approval for such an undertaking - and his esteem for his Ethiopian adviser-is demonstrated by another exchange from that same year, when he issued the following instructions to Bernardino Maffei, the secretary of Paul III:

I would like you to have the Indian [Ethiopian] and Maronite masses translated, to see if those provinces, converted by different apostles, have the same substance we have in terms of sacrifice, the intercession of saints, and the prayers for the dead. If I remember correctly brother Peter [Täsfa Seyon] . . . told me they [Ethiopians] have in the mass all these things. When we will deal with these things, it will be better to be informed. ${ }^{97}$

Though brief, these exchanges are revealing. Amid the conciliar negotiations, Cervini instructed his collaborators to enlist Täsfa Șeyon's expertise to procure, study, and print texts that could inform the upcoming battle for the fate of the Roman Church.

Either way, the orientalist-cardinal's collaboration with Täsfa Seyon was qualitatively different from the latter's prior work with European scholars, let alone other past collaborations. ${ }^{98}$ Potken, Giovio, Beccadelli, Góis, and the earliest geographers were motivated by distinct but fundamentally personal interests. Cervini, in contrast, did not personally engage in scholarship, but instead mobilised his institutional power and curial network towards the production of knowledge about Eastern and Ethiopian Christianity that was unprecedented in its coordination. In so doing, he thrust Täsfa Șeyon to the fore of Rome's emerging world of orientalist scholarship.

\section{An Ethiopian Contribution to Philologia Sacra}

Over the next decade, Täsfa Șeyon produced three major contributions to the developing field of Ethiopianist scholarship: his magnum opus Testamentum novum (1548-9), an edition of the Ge'ez New Testament with additional texts and commentary; Modus baptizandi (1548-9), a Latin edition of the Ethiopian baptismal rite; and Missa qua Ethiopes communiter utuntur (1548-9), a Latin edition of the Ethiopian missal with commentary. This multistage undertaking involved a series of interconnected scholarly projects and enlisted his considerable network of contacts in the Roman Curia and Ethiopian diaspora.

A preliminary issue was source material. Ethiopian manuscripts typically reached Rome via Ethiopian pilgrims or the Levantine diaspora, and glimpses of Täsfa Șeyon's procurement efforts appear in his correspondence with Contarini's contact $a b b a$ Yohannes. A polyglot from Venice-controlled Cyprus, the latter was connected to the Holy Land through Ethiopian and Venetian networks, and he apparently imported Ge'ez manuscripts from the Ethiopian community of his native island: in 1548, for example, he informed Täsfa Seyon that a manuscript had "arrived from Cyprus . . . in Venice," via the island's archbishop. ${ }^{99}$ Once obtained, the manuscripts were studied, corrected, and if necessary translated, in some cases through comparison. Sirleto described aspects of this undertaking in a letter to Cervini about the translation of the Ethiopian 
mass by Täsfa Șeyon and Yohannes, remarking "it is good to have many translations of the same matter, especially when they are by intelligent people, as S. Augustine also teaches in the book of Christian doctrine."100 The final stage was printing. In this, Täsfa Seyon faced a particular challenge with the Testamentum, as he noted in its Ge'ez preface: the project required the casting and use of fidäl moveable type that was unintelligible to the printers and which resulted in a considerable number of typographic errors. ${ }^{101}$ This linguistic hurdle was compounded by the inexperience of the printers, since the Sack of 1527 had devastated the city's thriving printing industry, including the press of the experienced Silber brothers, who had produced the Psalter. ${ }^{102}$ Täsfa Șeyon turned to the established Valerio Dorico, with whom he worked on the Testamentum between 1548 and 1549. ${ }^{103}$ It was arduous work, as he lamented: "If you only knew the effort and pain we put into the making of this book! For two years, day and night I, Täsfa Ṣeyon, and Tänśe'a Wäld, together with Zäsellasé, worked nonstop.”"104

This labour enjoyed Vatican support. Both the ledgers of the Apostolic Chamber, which record the papacy's public expenditures, and their counterparts in the Secret Treasury, which describe the pontiff's private expenses, document dozens of disbursements to Täsfa Seyon and his companions. ${ }^{105}$ For example, a 1538 transaction records provisions for "Indian [Ethiopian] friars," 106 while a 1541 entry notes a payment of 30 scudi to dress an Armenian bishop and "the Indian [Ethiopian] friars who are behind San Pietro." "107 Some disbursements specifically identify Täsfa Șeyon: he was the only Ethiopian mentioned by name in the personal ledger of Paul III and the family roll of Julius III, and was additionally the only member of Santo Stefano given disbursements for the entire community, a point that suggests the extent to which his position as a Farnese client shaped his relationship with other diasporic Ethiopians. ${ }^{108}$ In 1548 , he received "a subvention for certain Indian [Ethiopian] friars who will go to Jerusalem," 109 and between 1545-48, the Secret Treasury made monthly disbursements of "one gold scudo to Pietro Indiano for this month's salary of his teacher," his Latin tutor Antonio Lo Duca. ${ }^{110}$ Finally, the Vatican appears to have subsidised the Testamentum itself: the Secret Treasury lists a disbursement of "twelve scudi in gold to the Indian [Ethiopian] friars to pay [for] the tin in order to print in their language," 111 while Täsfa Seyon explained in his preface that "the sum of money that I gave to make the type and to print is 50 gold wäqét," an Ethiopian unit of measurement. ${ }^{112}$ The latter was a considerable investment: in the period in question, one wäqét was the equivalent of an ox in Ethiopia and ten drachma, or 34 grams, of gold in Europe. Täsfa Șeyon's "contribution" was thus a small fortune, suggesting it was at least partially derived from his Vatican patrons.

The outcome of this intellectual and capital investment was groundbreaking. The Testamentum was a monumental five hundred page work, featuring red and black ink and extensive woodcut illustrations, and its contents included the following: a Latin and $\mathrm{Ge}$ 'ez introduction and dedication; an introduction to fidäl that drew upon and corrected the similar section of the Psalter; the Eusebian Canon Tables; the editio princeps of the Ge'ez Gospels; selected epistles; the Acts of the Apostles, translated into Ge 'ez from Greek and Latin; the Anaphora; and a final dedication. It additionally features 
numerous colophons by Täsfa Seyon, which generally indicate the date of completion, list the individuals involved, and offer thanks to a range of benefactors past and present. One of these, which follows the Gospel of John, is a more substantial page-long historical statement about Täsfa Șeyon and Ethiopia.

Shorter but no less timely were his other two works, the Modus Baptizandi and Missa, which were published in 1549 as a single volume with distinct title pages. Together, they detailed the Ethiopian baptismal rite and liturgy, with a dedication to Paul III and a preface featuring Emperor Gälawdéwos's 1548 letter to the pontiff. For its printing, which did not require fidäl type, Täsfa Șeyon turned to the renowned Antonio Blado, the official printer of the Apostolic Chamber in the early 1530s and a past recipient of commissions from Cervini. ${ }^{113}$ Their subjects-Ethiopian mass and baptismal rituals-were then pressing topics at Trent: in 1547 Cervini told Sirleto that he was delighted to receive the translated mass from Täsfa Șeyon and Gualtieri, "the more gladly given that now in the Council the articles of the mass are being discussed."114

In sum, by the late 1540s Täsfa Șeyon was a prolific scholar and significant figure in the developing field of Eastern Christian-focused philologia sacra as well as the Roman printing landscape. In less than a decade, he made key texts and teachings of the Ethiopian Orthodox Church available to European readers for the first time, and there is inconclusive evidence that he hoped his publications would eventually reach readers in Ethiopia as well. Given that he was only in his late thirties when he fell sick and died, shortly after the printing of these works, one is left wondering about the nature of his future projects. His intellectual legacy, however, is more easily discerned.

\section{Rediscovering Täsfa Șeyon}

Täsfa Șeyon entered the modern academy through two Germans. The first was Hiob Ludolf, a seventeenth-century linguist, historian, and polymath who is widely regarded as the founder of the academic field of Ethiopian studies. A Leiden alumnus and adviser to the Duke of Saxe-Gotha, Ludolf was an admirer of Eastern Christianity, which he saw as proximate to the Lutheran Church, as well as an accomplished student of no less than six Semitic languages, including Ge'ez, Syriac, and Arabic. ${ }^{115}$ His Ethiopia-focused research culminated in a decade-long collaboration with $a b b a$ Gorgoryos of Santo Stefano, a monk and former courtier of Emperor Susenyos, which in turn led to a series of major studies that remained influential for centuries, including a $\mathrm{Ge}$ 'ez dictionary and grammar, a monumental history of Ethiopia, and an even more daunting supplement to this history in the form of a commentary. ${ }^{116}$

Täsfa Șeyon hides in the margins of this oeuvre. ${ }^{117}$ Ludolf began his study of Ethiopia using the extant Ethiopianist library and Ge'ez corpus in Europe, and his Ge'ez skills earned the respect of Gorgoryos at their first encounter at Santo Stefano, where Ludolf passed the monks' reading and translation test. The exam included scriptural passages, which tempts one to imagine queries based on the Testamentum. ${ }^{118}$ More certain, however, is that Täsfa Șeyon's work shaped Ludolf's subsequent scholarship, though 
nowhere near to the degree of his successor Gorgoryos. This connection began with Ludolf's Lexicon aethiopico-latinum (1661), which devoted an entry to Täsfa Șeyon that noted the Testamentum and curiously bestowed upon him the ecclesiastical title qomos, or abbot/superior - a title or honorific that possibly reflected his actual or perceived status at Santo Stefano. ${ }^{119}$ More substantially, this same work throughout offered illustrative usages via citations of the Gospels, effectively references to the Testamentum.

Täsfa Șeyon also appeared in Ludolf's equally enduring Historia Aethiopica (1681), which included a detailed chapter on Ge'ez literature. In it, Ludolf offered readers a systematic overview of the Ethiopian scriptures that was unprecedented in its detail, and he began his treatment of the New Testament with a discussion of Täsfa Seyon and his work, a review of the distinctions between the Testamentum and the conventional Ethiopian order of the scriptures, and Latin translations of several of Täsfa Șeyon's Ge 'ez commentaries. ${ }^{120} \mathrm{He}$ also used the Testamentum as a reference in his discussions of other topics, ${ }^{121}$ and his Commentarius (1691), which elaborated on the Historia, contained further discussions of the volume, many correcting the discussions of other European scholars. ${ }^{122}$ In short, the first major European study of the Ethiopian scriptures, a topic that had preoccupied Latin orientalists for over a century, rested on Täsfa Șeyon's foundational work. Together, Ludolf's Historia and Lexicon would remain standard references in Europe for the next two centuries, eventually underpinning the Ethiopia-related discussions of Enlightenment figures such as Denis Diderot. ${ }^{123}$

Täsfa Șeyon was further integrated into the field of Ethiopian studies by August Dillman. A theologian, linguist, and philologist trained by the wide-ranging Heinrich Fleischer, Dillman was a prolific Ethiopianist and Old Testament scholar who exemplified the growing confidence of mid-nineteenth-century German orientalists that the scientific quality of their analysis made them the supreme European arbiters of non-Western truth. ${ }^{124}$ Viewed by some today as a founder of the field, especially in terms of his contributions to Ge'ez studies, ${ }^{125}$ Dillman's reputation principally derives from his Old Testament translations and especially his Ge'ez-Latin Lexicon Linguae Aethiopicae (1865), which replaced Ludolf's earlier work as the standard reference of its kind. In its introduction, Dillman offered readers a concise survey of his vast source material, adding that in his view the scriptures were without equal for the study of Ge 'ez, since they were "the foundation and norm of all Abyssinian literature, to which other authors aligned their way of speaking and writing." 126 He then explained that in the case of the New Testament, he had reluctantly elected to use Täsfa Șeyon's error-strewn editio princeps instead of an alternative base manuscript, which effectively meant that the Testamentum underpinned his project. His innovative lexicon also compared translated Ge'ez texts with their Greek, Latin, Hebrew, and Syriac counterparts, and additionally employed Ethiopian grammars, dictionaries, and marginal commentary on lexical topics. The result was a massive reference tool filled with Gospel citations derived from the Testamentum, and Dillman's widely read Lexicon effectively incorporated Täsfa Seyon's magnum opus into the analytical apparatus of Semitic studies. By the early twentieth century, the prominence of the Testamentum was such that it served as the partial 
basis for two new European editions of the Ge'ez gospels intended to aid the Capuchin missionary enterprise in Eritrea and Ethiopia. ${ }^{127}$

This textual canonisation by European orientalists was followed by Täsfa Seyon's rediscovery by modern Ethiopian intellectuals. This process began in 1924, when Crown Prince Täfäri Mäkonnen - the future Emperor Haylä Śellasé-embarked on a historic European tour with a retinue of advisers and distinguished notables. As the first overseas mission of a de facto sovereign, the tour was a major milestone in Ethiopian statecraft, ${ }^{128}$ and it was additionally significant since it followed Ethiopia's contentious admission to the League of Nations and unfolded amid the continuing challenges to its sovereignty within the liberal-imperial international system. Täfäri Mäkonnen and his delegation spent several months touring the major European capitals to considerable press fanfare, and they eventually reached Rome for direct talks with the new prime minister, Benito Mussolini. ${ }^{129}$ The negotiations would prove to be the only face-to-face meeting of the two leaders.

What followed was an extraordinary moment of historical recuperation. After a conference at the Palazzo Venezia and tour of the Museo Coloniale, the Ethiopian dignitaries visited the Vatican for an audience with Pius XI and a visit to St. Peter's. In the dramatic and highly stylised retelling of then-blatta Heruy Wäldä Śellasé, the de facto minister of foreign affairs and the tour's erudite chronicler, the Ethiopian travelers eventually wearied of their Roman sightseeing and decided to stop in a quiet area behind the basilica. ${ }^{130}$ They then discovered that this resting space was adjacent to Santo Stefano, then rechristened as the Pontifical Ethiopian College but still known to Ethiopians-and now Eritreans - as Däbrä Qeddus Esțifanos. Heruy explained to his Amharic-speaking readers that a pontiff had long ago given this monastery to the Ethiopian pilgrims, and then narrated how he and the Crown Prince were warmly greeted by its current residents, a group of Ethiopian and Eritrean Catholic students. According to Heruy, their hosts delivered a series of richly symbolic and stylised Amharic, Tigrinya, and Ge'ez speeches and songs concerning the greatness of Täfäri Mäkonnen and the ties of faith that linked the distinguished visitors and the monastery residents with distant Ethiopia and wider Christendom. In the world of the text, a supposedly chance discovery had produced profound historical understanding.

After this lavish reception, the visiting Ethiopian dignitaries toured the premises of Santo Stefano. Heruy showed particular interest in the graves of the monastery's former residents, whose epitaphs he copied, translated into Amharic, and published in his printed account of the journey. This was the first account of Santo Stefano and its early modern residents for modern Ethiopian readers, and possibly the first domestic - as distinct from diasporic-reference to the residence in Ethiopian literature. Heruy presented the six epitaphs of $a b b a$ Habtä Maryam of Däbrä Guba'é, abba Täklä Haymanot of Däbrä Dima, abba Zäkonä, the monk Gäbrä Ś ennay, abba Ya eqob the follower of abunä Yostateyos, and finally Täsfa Șeyon. ${ }^{131}$ Reflecting upon the devotion of these pilgrims and the historical significance of this diasporic Ethiopian space at the heart of fascist Italy and the centre of global Catholicism, Heruy pithily remarked, "To find Ethiopian monasteries in Jerusalem and Rome is a reason for great pride to all the 
children of Ethiopia. And this [fact] explains why the Christianity of Ethiopia has lasted since many earlier times." ${ }^{132}$ Nearly five hundred years after Täsfa Seyon's departure from Ethiopia and arrival at Santo Stefano, Heruy textually repatriated him through the print medium they both celebrated, transforming him into a paragon of the Ethiopian ecumene. $^{133}$

In the decades to come, Heruy's discovery renewed interest in Täsfa Șeyon and Santo Stefano among Ethiopian and Eritrean intellectuals who sought to understand the nature of Ethiopia's stormy relationship with the wider world. Some Ge'ez Rite Eritrean Catholics, for example, viewed him as the forerunner of their non-Latin Catholic tradition — a position exemplified by Täklä Maryam Sämḥaray Sälim, who used Täsfa Șeyon's works to defend the Catholic Ge ez liturgy. ${ }^{134}$ Non-Catholic Ethiopian scholars also began to consider Täsfa Șeyon's historical significance, following Heruy’s work as well as the developing European literature on Santo Stefano. In the mid-1960s, the eminent and widely read historian Täklä Șadeq Mäk ${ }^{\mathrm{w}}$ uriya discussed the monastery in his rich account of the reign of Emperor Gälawdéwos, which he understood within the conjuncture of the Ottoman-Portuguese imperial contest and the Catholic missionary enterprise in Ethiopia. ${ }^{135}$ Some years later, on the eve of the Ethiopian revolution of 1974, the historian Alämé Ešäté began his study of Ethiopian diasporic history with a discussion of Täsfa Șeyon, who he suggested inaugurated an outward-looking educational quest that stretched from the early modern era through to the student movements of the 1960s. ${ }^{136}$ In these same years, abba Samuel Asghedom, the Catholic rector of the Pontifical Ethiopian College, argued that Täsfa Șeyon and the other early modern residents of Santo Stefano offered a model of dialogic intercultural scholarly inquiry that could usefully instruct what had now become the interdisciplinary field of Ethiopia-focused area studies. ${ }^{137}$ If Ludolf and Dillman had viewed Täsfa Șeyon as an instrument of Western understanding, these Ethiopian and Eritrean writers instead joined Heruy in imagining him as a harbinger and synecdoche of Ethiopia's encounter with the West, in all its fraught complexity.

\section{Conclusion}

Arriving in Rome as a pilgrim and refugee, Täsfa Șeyon eventually became a leading Vatican authority on Ethiopia and Ethiopian Orthodox Christianity. In the decade after he reached the small community at Santo Stefano, he became a trusted adviser to the Curia during the stormy years of the Council of Trent, a favoured client of Paul III, and a close collaborator with future pontiff Cardinal Cervini, and he ultimately became a prominent participant in the emerging Catholic-led field of Eastern Christian-focused oriental studies. This short but unusual career had a rich legacy. Just before his sudden death at a relatively young age, his compatriots at Santo Stefano referred to him as "our spiritual father and master [mämher]" in the rules written to regulate life at their residence, and in a symbolic gesture, they chose to record these rules in their library's copy of his Testamentum. ${ }^{138}$ In the decades that followed, his students and collaborators applied the knowledge derived from his teachings in their own works, and over the 
next three centuries, Täsfa Șeyon's magnum opus became a standard reference work for European researchers interested in Ethiopia and its Ge'ez literary heritage.

This enduring impact suggests Täsfa Șeyon's fundamental similarity to other Bessarione-like early modern Eastern Christian knowledge brokers. These include Moses of Mardin, who resided alongside Täsfa Șeyon at Santo Stefano and was similarly a client of Cervini, and who additionally collaborated with Guillaume Postel and Johann Albrecht Widmannstetter on the editio princeps of the Syriac New Testament; Ignatius $\mathrm{Na}$ 'matallah, the exiled Patriarch of Antioch who became the tutor of Joseph Scaliger; Yusuf ibn Abu Dhaqn, the Cairene Coptic convert to Catholicism who spurred the development of Coptic studies in Europe; and Būlus al-Haddār, the Maronite bibliographer and scholar widely viewed as a progenitor of Portuguese oriental studies. Like Täsfa Șeyon and the more famous Leo Africanus, these intermediaries were key agents of intercultural inquiry and educators of the first generations of early modern orientalists, even if these contributions were subsequently diminished by later Western specialists who dismissed the authority of these Eastern Christian interlocutors because of their perceived cultural hybridity and open connection to the Catholic missionary enterprise. ${ }^{139}$

Täsfa Șeyon's intellectual influence and enduring publications contributed to the bourgeoning body of religiously-motivated orientalist learning that would in the late sixteenth and early seventeenth century make Rome the leading centre of orientalist scholarship in Europe, laying the foundation for its ostensibly secular and academic Franco-German eighteenth-century successor. As Keller and Irigoyen-García have argued more broadly, this early modern meeting of European and extra-European minds generated something previously unknown to either: a European-dominated specialised field of orientalist learning predicated on authorial competition, linguistic competency, and the purported systematic and integrated analysis of extra-European societies through the study of their texts. ${ }^{140}$ It is for this reason that Täsfa Șeyon deserves to be remembered as a founder of Ethiopian studies.

\section{Acknowledgements}

The authors thank Abebe Ambatchew, Gianfranco Armando, Sanda Bob, David D. Daniels III, Ermias Zemichael, Kathleen Furr, Nikola Golubović, Gabriele Natta, and Ruth Iyob. This research was funded by an American Philosophical Society Franklin Research Grant, an American University of Sharjah Faculty Research Grant, and an American University of Sharjah Open Access Grant. Transliteration follows the Encyclopaedia Aethiopica (EA) system, substituting $e$ for the fifth order and $e$ for the sixth order vowels. Dates in the Ethiopian calendar are designated AM, for 'amätä mehrät.

\section{Bibliography}

\section{Unpublished Primary Sources}

Biblioteca Apostolica Vaticana, Vatican City (BAV) 
-Ott. Lat. 2789

-R.I.IV 2218

-Vat. Et. 16

-Vat. Lat. 6177

-Vat. Lat. 6178

Biblioteca Comunale degli Intronati, Siena (BCI)

-Ms. DV 13

Archivio di Stato di Roma, Rome (ASR)

-Camerale I, Giustificazioni di Tesoreria, busta 2, fascicolo 7

-Camerale I, busta 2, fascicolo 13

-Camerale I, registro 1290

-Camerale I, registro 1293

-Camerale I, registro 1349

Hill Monastic Manuscript Library, Collegeville (EMML)

-Gäbrä Mika'él Germu, "Mäsäḥafä meker," EMML 1467

\section{Published Primary Sources}

Africanus, Leo. "Descrittione dell'Africa." In Delle navigationi et viaggi, ed. Giovanni Battista Ramusio, 1-95. Venice: Giunti, 1550.

Álvares, Francisco. La historia d'Ethiopia di Francesco Alvarez, ed. Osvaldo Raineri. Vatican City: BAV, 2007.

Álvares, Francisco. The Prester John of the Indies, ed. C. F Beckingham and G. W. B. Huntingford, trans. H. E. J. Stanley. Cambridge: Hakluyt Society, 1961.

Álvares, Francisco. Verdadeira informação sobre das terras do Preste João das Indias. Lisbon: 1540.

[Anonymous]. Legatio David Aethiopiae regis. Bologna: Iacobum Kemolen Alostensem, 1533.

Beccari, Camillo. Rerum Aethiopicarum scriptores occidentales inediti a saeculo XVI ad XIX. Vol. 10. Rome: C. De Luigi, 1903.

Chaîne, Marius. "Un monastère éthiopien a Rome aux XV et XVI siècle, Santo Stefano dei mori." Mélanges de la faculté orientale 5 (1911): 1-36.

Conti Rossini, Carlo. "Storia di Lebna Dengel re d'Etiopia sino alle prime lotte contro Ahmad Ben Ibrahim." Rendiconti della Reale Accademia dei Lincei 3:1 (1894): 617-40.

Crawford, Osbert Guy Stanhope, ed. Ethiopian Itineraries. Cambridge: Hakluyt Society, 1958.

Diderot, Denis, and Jean le Rond d'Alembert, eds. Encyclopédie. University of Chicago: ARTFL Encyclopédie Project, 2017.

Dillman, August. Lexicon Linguae Aethiopicae cum indice Latino. Leipzig: Weigel, 1865.

'Enbaqom. Anqașa amin (La Porte de la Foi): Apologie éthiopienne du Christianisme, contre l'Islam à partir du Coran, trans. Emeri Johannes van Donzel. Leiden: Brill, 1969.

Erasmus, Desiderius. Ecclesiastae sive de ratione concionandi libri quatuor, ed. Friedrich August Klein. Leipzig: Libraria Weidmannia, 1820.

Giovio, Paolo. Historiarum sui temporis, vol. 1. Paris: Vascosanus, 1553.

—. Pauli Iovii elogia virorum bellica virtute illustrium. Basel: Perna, 1575.

Góis, Damião de. Fides, religio, moresqve AEthiopvm svb imperio Preciosi Ioannis. Leuven: Ex officina Rutgeri Rescij, 1540.

—. Legatio magni indorum imperatoris Presbyteri Ionnis. Antwerp: Ioannes Grapheus, 1532.

Grébaut, Sylvain and Tisserant, Eugène. Codices aethiopici vaticani et borgiani: Barberinianus orientalis 2, Rossianus 865. Vatican City: BAV, 1935.

Guidi, Ignazio. "La prima stampa del Nuovo Testamento in etiopico fatta in Roma nel 1548-1549." Archivio della regia società romana di storia di patria 9 (1886): 273-8. 
Heruy Wäldä Śellasé. Bä ityopya yämmiggäñ̃u bäge ezenna bamariñña $q^{w} a q^{w} a$ yätäsafu yämäșaheft katalog. Addis Ababa: Täfäri Mäkonnen Press, 1920AM.

—_. Dästanna käbbär. Yä ityopya mängeśt 'alga wärašenna 'endärasé le ul täfäri mäkonnen wädä 'awropa sihédunna simmälläsu yämängädaččäw 'akk $a h^{w} a n$. Addis Ababa: Goh Șebah, 1926ஷ்M.

—. Wazéma. Bämagestu yä ityopyan nägästat yätarik bä’al lämakbär. Addis Ababa: Goh Șebah, 1926AM.

Jorga, Nicola. "Cenni sulle relazioni tra l'Abissinia e l'Europa cattolica nei secoli XIV-XV." In Centenario della nascita di Michele Amari, 139-50. Palermo: Stabilimento tipografico Virzì, 1910.

Lefevre, Renato. "Documenti e notizie su Tasfā Șeyon e la sua attivita romana nel sec. XVI." Rassegna di studi etiopici 24 (1969): 74-133.

—. "Documenti pontifici sui rapporti con l'Etiopia nei secoli XV e XVI." Rassegna di studi etiopici 5 (1947): 17-41.

Ludolf, Hiob. Confessio fidei Claudii regis AEthiopiae. London: Roycroft, 1661.

_. Iobi Ludolfi ad suam historiam aethiopicam antehac editam commentarius. Frankfurt: Zunner, 1691.

—. Iobi Ludolfi historia aethiopica. Frankfurt: Zunner, 1681.

_. Jobi Ludolfi I. C. lexicon Aethiopico-Latinum, ed. Johann Michael Wansleben. London: Roycroft, 1661.

Ludolf, Hiob. Jobi Ludolfi J. C. grammatica Aethiopica, ed. Johann Michael Wansleben. London: Roycroft, 1661.

Manuel I. Epistola invictissimi regis portugalliae ad Leonem X.P.M. Lisbon: 1521.

Matos, Luís de, ed. Imagens do oriente no século XVI. Lisbon: Imprensa Nacional, 1985.

Merkle, Sebastian. Concilium Tridentinum. Freiburg: Herder, 1911.

Nosnitsin, Denis, trans. “'A History That Was Found': A Recent Chapter in the Historiography of Däbrä Libanos.” Africana Bulletin 54 (2006): 35-53.

Perruchon, Jules, trans. "Histoire d'Eskender, d'“Amda-Ṣeyon II et de Nâ'od, rois d'Éthiopie, texte éthiopien inédit comprenant en outre un fragment de la chronique de Ba'eda-Mâryâm, leur prédécesseur, et traduction." Journal Asiatique 3 (1894): 319-66.

— nationale de Paris et traduction." Revue sémitique 1 (1893): 274-86.

Petrus Abbas [Täsfa Șeyon]. Missa qua Ethiopes communiter ututur [. . . ]. Rome: Antonium Bladum, 1549.

Petrus Abbas [Täsfa Șeyon]. Modus baptizandi, preces et benedictiones quibus ecclesia Ethiopum utitur [... ]. Rome: Antonium Bladum. 1549.

Petrus Ethyops [Täsfa Șeyon]. Testamentum novum cum epistola pauli ad hebreos [ . . . ]. Rome: Valerius Doricus, 1548.

Potken, Johannes, and Tomas Wäldä Samu'él. Psalterium David et cantica aliqua in lingua Chaldea. Rome: Marcellus Silber, 1513.

Ramusio, Giovanni Battista. Delle navigationi et viaggi. Venice: Giunti, 1550.

Razzi, Serafino. Vite dei santi, e beati cosi uomini, come donne del sacro ordine de' FF. Predicanti. Florence: Sermartelli, 1577.

Salmeron, Alfonso. Epistolae Alphonsi Salmeronis Societatis Jesu. Madrid: Gabrielis Lopez del Horno, 1906.

Solomon Gebreyes Beyene, trans. "The Chronicle of King Gälawdewos (1540-1559)." PhD diss., University of Hamburg, 2016.

Thomas, Henry. The Discovery of Abyssinia by the Portuguese in 1520. London: British Museum, 1938.

Victorius, Marianus. Chaldeae seu Aethiopicae linguae institutions. Rome: V. Doricus, 1552. 
- Chaldeae seu aethiopicae linguae institutions. Rome: Propaganda Fide, 1630.

Whiteway, Richard Stephen, ed. The Portuguese Expedition to Abyssinia in 1541-1543 as Narrated by Castanhoso. London: The Hakluyt Society, 1902.

\section{Secondary Sources}

Alämé Ešäté. "Bäqäddemo zämänat kä1889 'a.m. bäfit weç 'agar yätämmaru 'ityopyaweyanoč tarik." Ethiopian Journal of Education 6:1 (1973): 115-48.

Adankpo-Labadie, Olivia. "A Faith between Two Worlds: Expressing Ethiopian Devotion and Crossing Cultural Boundaries at Santo Stefano dei Mori in Early Modern Rome." In In $A$ Companion to Religious Minorities in Early Modern Rome, ed. Emily Michelson and Matthew Coneys, 169-91. Leiden: Brill, 2020.

App, Urs. The Birth of Orientalism. Philadelphia: University of Pennsylvania Press, 2010.

Asfa-Wossen Asserate. King of Kings: The Triumph and Tragedy of Emperor Haile Selassie I of Ethiopia, trans. Peter Lewis. London: Haus, 2015.

Aubin, Jean. "Le Prêtre Jean Devant La Censure Portugaise." Bulletin des études portugaises et brésiliennes 41 (1980): 186-7.

Barberi, Francesco. "I Dorico, tipografi a Roma nel cinquecento." La Bibliofilia 67:2 (1965): 221-59.

Barberi, Francesco. "Libri e stampatori nella Roma dei papi (con 8 tavv. ft)." Studi Romani 13:4 (1965): 433-56.

Bausi, Alessandro. "La versione etiopica della Epistola di Eusebio a Carpiano." In Aethiopia Fortitudo ejus. Studi in onore di Monsignor Osvaldo Raineri in occasione del suo $80^{\circ}$ compleanno, ed. Rafał Zarzeczny, 107-35. Rome: Pontificio Istituto Orientale, 2015.

Bausi, Alessandro. "On Editing and Normalizing Ethiopic Texts." In 150 Years after Dillmann's Lexicon: Perspectives and Challenges of Ga 'az Studies, edited by Alessandro Bausi, 43-102. Wiesbaden: Harrassowitz, 2016.

Beckingham, Charles Fraser, and Bernard Hamilton, eds. Prester John, the Mongols, and the Ten Lost Tribes. Aldershot: Ashgate, 1996.

Bernardinello, Silvio. Autografi greci e greco-latini in Occidente. Padua: CEDAM, 1979.

Burke, Edmund, and David Prochaska. "Introduction." In Genealogies of Orientalism, ed. Burke and Prochaska, 1-71. Lincoln: University of Nebraska Press, 2009.

Burnett, Charles, Alastair Hamilton, and Jan Loop, eds. The Teaching and Learning of Arabic in Early Modern Europe. Leiden: Brill, 2017.

Cardinali, Giacomo. "Ritratto di Marcello Cervini en orientaliste." Bibliothèque d'humanisme et renaissance 80:1, 2 (2018): 77-98, 325-43.

Coudert, Allison. “Orientalism in Early Modern Europe?” In East Meets West in the Middle Ages and Modern Times, ed. Albrecht Classen, 715-56. Boston: De Gruyter, 2013.

Daniels III, David D., and Lawrence Anglin. "Luther and the Ethiopian Deacon." Lutheran Quarterly 32:4 (2018): 428-34.

Davis, Asa J. "Background to the Zaaga Zab Embassy: An Ethiopian Diplomatic Mission to Portugal (1529-1539)." Studia 32 (1971): 211-302.

Davis, Natalie Zemon. Trickster Travels: A Sixteenth-Century Muslim between Worlds. New York: Hill and Wang, 2006.

Debrunner, Hans Werner. Presence and Prestige: Africans in Europe. Basel: Basler Afrika Bibliographien, 1979.

De Lorenzi, James. Guardians of the Tradition: Historians and Historical Writing in Ethiopia and Eritrea. Rochester, N.Y.: University of Rochester Press, 2015.

Edson, Evelyn. The World Map, 1300-1492. Baltimore: Johns Hopkins University Press, 2007. Eliav-Feldon, Miriam. Renaissance Impostors and Proofs of Identity. London: Palgrave, 2012.

Encyclopaedia Aethiopica, ed. Siegbert Uhlig and Alessandro Bausi. 5 vols. Wiesbaden: Harrassowitz, 2003-2014. (EA) 
Esche-Ramshorn, Christiane. "Multi-Ethnic Pilgrim Centre: Sharing Sacred Space in Renaissance Rome, the Diversity of Religions and the Arts." In Fremde in der Stadt, ed. Peter Bell, 171-94. Frankfurt: Lang, 2010.

Euringer, Sebastian. "Das Epitaphium Des Tasfâ Șejon." Oriens Christianus, 3rd ser., 1 (1926): 49-66.

Falchetta, Piero. Fra Mauro's Map of the World. Turnhout: Brepols, 2006.

Furey, Constance M. Erasmus, Contarini, and the Religious Republic of Letters. Cambridge: Cambridge University Press, 2006.

Ghobrial, John-Paul. "The Archive of Orientalism and Its Keepers." Past and Present 230, supplement 11 (2016): 90-111.

Ghobrial, John-Paul. "The Life and Hard Times of Solomon Negri.” In The Teaching and Learning of Arabic in Early Modern Europe, ed. Burnett, Hamilton, and Loop, 310-31. Leiden: Brill, 2017.

Girard, Aurélien. "Was an Eastern Scholar Necessarily a Cultural Broker in Early Modern Europe? Faustus Naironus (1628-1711), the Christian East, and Oriental Studies." Proceedings of the British Academy 225 (2019): 240-63.

—. "Teaching and Learning Arabic in Early Modern Rome: Shaping a Missionary Language." In The Teaching and Learning of Arabic in Early Modern Europe, edited by Jan Loop, Alastair Hamilton, and Charles Burnett, 189-212. Leiden: Brill, 2017.

Gleason, Elisabeth G. Gasparo Contarini. Berkeley: University of California Press, 1993.

Haberland, Eike. "Hiob Ludolf, Father of Ethiopian Studies in Europe." In Proceedings of the Third International Conference of Ethiopian Studies, Addis Ababa 1966, ed. Richard Pankhurst and Stanislaw Chojnacki, 131-6. Addis Ababa: Institute of Ethiopian Studies, 1969-70.

Hallaq, Wael. Restating Orientalism: A Critique of Modern Knowledge. New York: Columbia University Press, 2018.

Hamilton, Alastair, The Copts and the West, 1439-1822. New York: Oxford University Press, 2006.

—_ "An Egyptian Traveler in the Republic of Letters." Journal of the Warburg and Courtauld Institutes 57 (1994): 123-50.

Hamilton, Alastair, Maurits H. van den Boogert, and Bart Westerweel, eds. The Republic of Letters and the Levant. Leiden: Brill, 2005.

Heschel, Susanna, and Umar Ryad, eds. The Muslim Reception of European Orientalism. New York: Routledge, 2018.

Hirsch, Elisabeth Feist. Damião de Gois: The Life and Thought of a Portuguese Humanist, 15021574. The Hague: Martinus Nijhoff, 1967.

Hitti, Phillip K. "The First Book Printed in Arabic." Princeton University Library Chronicle 4:1 (1942): 5-9.

Hudon, William V. Marcello Cervini and Ecclesiastical Government in Tridentine Italy. DeKalb: Northern Illinois University Press, 1992.

Juel-Jensen, Bent. "Potken's Psalter and Tesfa Tsion's New Testament, Modus Baptizandi and Missal." Bodleian Library Record 15 (1994): 480-96.

Keller, Marcus, and Javier Irigoyen-García, eds. The Dialectics of Orientalism in Early Modern Europe. New York: Palgrave Macmillan, 2018.

Kelly, Samantha. "The Curious Case of Ethiopic Chaldean: Fraud, Philology, and Cultural (Mis) Understanding in European Conceptions of Ethiopia.” Renaissance Quarterly 68:4 (2015): 1227-64.

Kelly, Samantha, and Denis Nosnitsin. "The Two Yohannoses of Santo Stefano Degli Abissini, Rome." Manuscript Studies 2:2 (2017): 392-426.

Kennerley, Sam. "Ethiopian Christians in Rome, c.1400-c.1700." In A Companion to Religious Minorities in Early Modern Rome, ed. Emily Michelson and Matthew Coneys, 142-68. Leiden: Brill, 2020. 
Krek, Miroslav. "The Enigma of the First Arabic Book Printed from Movable Type." Journal of Near Eastern Studies 38:3 (1979): 203-12.

Lefevre, Renato. “Appunti sull'ospizio di S. Stefano degli 'indiani' nel Cinquecento." Studi Romani 15:1 (1967): 16-33.

_. "Giovanni Potken e la sua edizione romana del salterio in etiopico (1513)." La Bibliofilia 68:3 (1966): 300-6.

—. "L'Ambasceria di David re d'Etiopia a Clemente VII (1533)." Accademie e biblioteche d'Italia 34:4, 5-6 (1966): 230-48.

_. "Realtà e leggenda dell'Etiopia nelle «Historiae» di Paolo Giovio." Gli annali dell'africa italiana 4 (1941): 1189-99.

Marchand, Suzanne. German Orientalism in the Age of Empire. New York: Cambridge University Press, 2009.

Marcocci, Giuseppe. "Gli umanisti italiani e l'impero portoghese: Una interpretazione della Fides, Religio, Moresque Æthiopum di Damião de Góis.” Rinascimento 45 (2005): 307-66.

Marcus, Harold. Haile Sellassie I: The Formative Years, 1892-1936. Lawrenceville, N.J.: Red Sea Press, 1995.

Mauro da Leonessa. Santo Stefano Maggiore degli Abissini e le relazioni romano-etiopiche. Vatican City: Tipografia Poliglotta Vaticana, 1929.

Naithani, Sadhana. In Quest of Indian Folktales: Pandit Ram Gharib Chaube and William Crooke. Bloomington: Indiana University Press, 2006.

Natta, Gabriele. "L'enigma dell'Etiopia nel Rinascimento italiano: Ludovico Beccadelli tra inquietudini religiose e orizzonti globali." Rinascimento 55 (2015): 275-309.

Pankhurst, Richard. "A Preliminary History of Ethiopian Measures, Weights and Values (Part 3)." Journal of Ethiopian Studies 8:1 (1970): 59-62.

Paschini, Pio. "Un cardinale editore: Marcello Cervini." In Miscellanea di scritti di bibliografia ed erudizione in memoria di Luigi Ferrari, ed. Luigi Ferrari, 383-413. Florence: Olschki, 1952.

Pastor, Ludwig. The History of the Popes, from the Close of the Middle Ages, ed. Ralph Francis Kerr. 38 vols. London: Kegan Paul, 1910.

Pouillon, François, and Jean-Claude Vatin, eds. Après l'orientalisme. Paris: Karthala, 2011.

Proverbio, Delio Vania. "Santo Stefano degli Abissini." La parola del passato 66 (2011): 50-68.

Quaranta, Chiara. Marcello II Cervini (1501-1555). Bologna: Il Mulino, 2010.

Raineri, Osvaldo. "Gli studi etiopici nell'età di Giovio." In Atti del Convegno Paolo Giovio, ed. T. C. P. Zimmerman, 117-31. Como: 1985.

Raineri, Osvaldo. "La versione etiopica dei Vangeli." In I vangeli dei popoli: la parola $e$ l'immagine del Cristo nelle culture e nella storia, ed. Francesco d'Aiuto, Giovanni Morello, and Ambrogio Piazzoni, 61-6. Rome: Biblioteca Apostolica Vaticana, 2000.

Raineri, Osvaldo, and Ilaria Delsere. Chiesa di S. Stefano dei Mori. Vatican City: Edizioni Capitolo Vaticano, 2015.

Relaño, Francesc. The Shaping of Africa. Burlington: Ashgate, 2002.

Romani, Valentino. "La Stampa Del N.T. in Etiopico (1548-49)." In Studi di biblioteconomia e storia del libro in onore di Francesco Barberi, 481-98. Rome: Associazione italiana biblioteche, 1976.

Rubiés, Joan-Pau. Travel and Ethnology in the Renaissance. New York: Cambridge University Press, 2000.

Salvadore, Matteo. "African Cosmopolitanism in the Early Modern Mediterranean." Journal of African History 58:1 (2017): 61-83.

. The African Prester John and the Birth of Ethiopian-European Relations 1402-1555. New York: Routledge, 2016.

—. "The Ethiopian Age of Exploration: Prester John's Discovery of Europe, 1306-1458." Journal of World History 21:4 (2010): 593-627. 
_. "Gaining the Heart of Prester John." World History Connected 10:3 (2013), http:// worldhistoryconnected.press.illinois.edu/10.3/forum_salvadore.html.

- "The Jesuit Mission to Ethiopia (1555-1634) and the Death of Prester John." In World-Building and the Early Modern Imagination, ed. Allison B. Kavey, 141-72. New York: Palgrave Macmillan, 2010.

Samuel Asghedom. "Contributo dell'ospizio di Santo Stefano degli Abissini agli studi etiopici in Europa." In IV Congresso internazionale di studi etiopici (Roma, 10-15 Aprile 1972), ed. Enrico Cerulli, 389-404. Rome: Accademia nazionale dei lincei, 1974.

Stolzenberg, Daniel. "Les 'langues orientales' et les racines de l'orientalisme académique: une enquête préliminaire." Dix-septième siècle 268 (2015): 409-26.

Subrahmanyam, Sanjay. "Connected Histories." Modern Asian Studies 31:3 (1997): 735-62.

—. "On World Historians in the Sixteenth Century." Representations 91 (2005): 26-57.

Taddesse Tamrat. Church and State in Ethiopia, 1270-1527. Oxford: Oxford University, 1972.

Täklä Maryam Sämḥaray Sälim. La messe éthiopienne. Rome: Tipografia San Pio X, 1937.

Täklä Șadeq Mäk ${ }^{\mathrm{w} u r i y a . ~ Y a ̈ ~ i t y o p y a ~ t a r i k ~ k a ̈ ~ a s ̦ e ́ ~ l e b n a ̈ ~ d e n g e l ~ ' e s k a ̈ ~ ' a s ̦ e ́ ~ t e ́ w o d r o s . ~ A d d i s ~ A b a b a: ~}$ Ministry of Education, 1969.

Tedeschi, Salvatore. "Paolo Giovio e la conoscenza dell'Etiopia nel rinascimento." In Atti del Convegno Paolo Giovio, ed. T. C. P. Zimmerman, 93-116. Como: 1985.

Tinto, Alberto. Gli annali tipografici di Eucario e Marcello Silber (1501-1527). Florence: L.S. Olschki, 1968.

Vaccaro-Sofia, E. "Documenti e precisazioni su Antonio Blado ed eredi tipografi camerali del sec. XVI." Bollettino dell'istituto di patologia del libro 1-4 (1950): 48-85.

Vedovato, Giuseppe. Gli accordi italo-etiopici dell'agosto 1928. Florence: Poligrafico Toscano, 1956.

Vermeulen, Han. Before Boas: The Genesis of Ethnography and Ethnology in the German Enlightenment. Lincoln: University of Nebraska Press, 2015.

Wilkinson, Robert. Orientalism, Aramaic, and Kabbalah in the Catholic Reformation. Leiden: Brill, 2007.

Zarzeczny, Rafał. "Su due manoscritti etiopici della biblioteca casanatense a Roma." In Aethiopia fortitudo ejus, ed. Rafał Zarzeczny, 501-37. Rome: Pontificio Istituto Orientale, 2015.

Zuurmond Rochus. Novum Testamentum Aethiopice. Stuttgart: Franz Steiner Verlag Wiesbaden, 1989.

\section{Notes}

- Matteo Salvadore is Associate Professor of History at American University of Sharjah.

* James De Lorenzi is Associate Professor of History at John Jay College, City University of New York.

1 Pastor, Popes, 13:1-44.

2 Merkle, Concilium Tridentinum, 2:87.

3 In early modern Europe, East Africa was considered one of the Indies: Relaño, Shaping of Africa, 1-72.

4 Täsfa Seyon's attendance is recorded in the diary of Angelo Massarelli: Merkle, Concilium Tridentinum, 15, 126-8. It is further attested by the invoice of the tailor who supplied the Curia for the funeral: "Computa Pietrantonij Guasconi," Camerale I, Giustificazioni di Tesoreria, busta 2, fascicolo 7, f. 13, ASR.

5 Vat. Et. 16, f. 55v, BAV.

6 Petrus Ethyops [Täsfa Ṣeyon], Testamentum; Petrus Abbas [Täsfa Șeyon], Modus baptizandi and Missa.

7 Mauro da Leonessa, Santo Stefano; and Lefevre, "Appunti" and "Documenti Pontifici."

8 Salvadore, The African Prester John and "African Cosmopolitanism"; Kelly and Nosnitsin, "Yohannəses"; Raineri and Delsere, Chiesa di. S. Stefano; 
Vania Proverbio, "Santo Stefano"; Kennerley, "Ethiopian Christians"; and Adankpo-Labadie, "Faith between Two Worlds."

9 Euringer, "Epitaphium"; and Lefevre, "Documenti e notizie."

10 EA, 5:525-8.

11 Zuurmond, Testamentum, esp. 39, 68-9, 139 , and 224-5.

12 Bausi, "Eusebio," esp. 109-10; and Raineri, "Vangeli." 61-6. See also Juel-Jensen, "Psalter," 483-96; Romani, "Stampa," 481-98; and Guidi, "Nuovo Testamento," 273-4.

13 Debrunner, Presence and Prestige, 512; and Salvadore, "Gaining the Heart of Prester John," 186-97, and "Jesuit Mission," 150.

14 Stolzenberg, "Langues orientales," esp. 422-3.

15 Keller and Irigoyen-García, Dialectics of Orientalism; Burnett, Hamilton, and Loop, The Teaching and Learning of Arabic; App, Birth of Orientalism; Wilkinson, Orientalism, Aramaic, and Kabbalah; Hamilton, Copts and the West; and Hamilton, van den Boogert, and Westerweel, Republic of Letters. See also Coudert, "Orientalism in Early Modern Europe?"; Burke and Prochaska, "Introduction"; and Hallaq, Restating Orientalism.

16 Vermeulen, Boas; and Rubiés, Travel.

17 Keller and Irigoyen-García, Dialectics of Orientalism, "Introduction," 1-2.

18 Girard, "Faustus Naironus"; Ghobrial, "Archive of Orientalism" and "Solomon Negri"; Hamilton, "Egyptian Traveler"; and Zemon Davis, Trickster Travels.

19 Heschel and Ryad, Reception of Orientalism; Pouillon and Vatin, Après l'orientalisme; and Naithani, Indian Folktales.

20 Girard, "Arabic."

21 Subrahmanyam, "Connected Histories."

22 Vat. Et. 16, f. 55v, BAV; and Petrus Ethyops [Täsfa Șeyon], Testamentum, 101.

$23 E A, 2: 25-8$.
24 EA, 2:280-2; and Heruy Wäldä Śellasé, Wazéma, 101-20.

25 EA, 2:831-4.

26 'Enbaqom, Anqașa amin.

$27 E A, 3: 293-5 ; 1: 56-7 ; 1: 472-3$; and 2:812-4.

28 Petrus Ethyops [Täsfa Șeyon], Testamentum, 113, with “"Enbäqom”; and Vat. Et. 16, f. 55v, BAV. On the term, $E A$, 5:525.

29 On these, see Taddesse Tamrat, Church and State.

30 Täsfa Șeyon to Pietro Paolo Gualtieri, 17 September 1547, Ms. DV 13, f. 252r, BCI; and Ott. Lat. 2789 f. $111 \mathrm{v}, \mathrm{BAV}$.

31 Perruchon, "Lebna-Dengel," 274-86; and Conti Rossini, "Lebna Dengel," 617-40.

32 Solomon Gebreyes Beyene, "Gälawdewos," 186-7 and 212-3; and Perruchon, "Eskender," 319-66.

$33 E A, 2: 27$.

34 Petrus Ethyops [Täsfa Șeyon], Testamentum, 100v. The text has "mäsärri."

35 Solomon Gebreyes Beyene, "Gälawdewos," 23-4.

36 EA, 2:27.

37 Heruy Wäldä Śellasé, Wazéma, 110; Hueruy Wäldä Śellasé, Katalog, 6; and Nosnitsin, "Däbrä Libanos," 35-53.

38 For example, the ambassador Șägga Zä'ab reportedly "spoke a little Italian" because he had already been to Europe, and likely Rome: Álvares, Prester John, 182, 420.

39 Mauro da Leonessa, Santo Stefano; and Chaîne, "Santo Stefano."

40 Petrus Ethyops [Täsfa Șeyon], Testamentum, 225r.

41 Grébaut and Tisserant, Codices, 245-8; Zarzeczny, "Manoscritti," 509; and Mauro da Leonessa, Santo Stefano, 189-202. In 1516, Tomas Wäldä Samu'él reported thirty residents: Razzi, Vite, 294.

42 Leo Africanus, "Descrittione," 1v. This observation likely mistook branding for 
the practice of forehead tattooing: $E A$, 5:278-82.

43 Esche-Ramshorn, "Pilgrim Centre."

44 Salvadore, The African Prester John, 26-88; Relaño, Shaping of Africa, 5572; Beckingham and Hamilton, Prester John; and Edson, World Map.

45 Jorga, "Cenni."

46 Falchetta, Fra Mauro, 201.

47 Crawford, Itineraries.

48 Salvadore, The African Prester John, 4, 46-7, 62-4.

49 Stolzenberg, "Langues orientales."

50 Hitti, "First Book"; and Krek, "Enigma."

51 Kelly, "Chaldean."

52 Lefevre, "Potken," 300-6.

53 Tinto, Silber, 92; and Barberi, "Dorico," 222.

54 Potken and Tomas Wäldä Samu'él, Psalterium, unpaginated leaf.

55 Ramusio, Navigationi et viaggi, 191-203.

56 Thomas, Abyssinia.

57 Manuel I, Epistola.

58 Góis, Legatio.

59 Salmeron, Epistolae, 33-6.

60 Whiteway, Expedition, 129-30.

61 Whiteway, Expedition, 130.

62 Raineri, "Giovio," 118.

63 Marcocci, "Umanisti," 307-66, 317-8.

64 Góis, Legatio.

65 Lefevre, "David," 230-48, 324-38; and Salvadore, "African Cosmopolitanism," 70-1.

66 Álvares, Preste João.

67 De Matos, Imagens do oriente, esp. 56-8.

68 Ramusio, Navigationi et viaggi, 191-281.

69 Lefevre, "Giovio," 1189-99; and Tedeschi, "Giovio," 93-116.

70 Giovio, Historiarum.

71 Giovio, Historiarum, 1:218r.

72 Giovio, Historiarum, 1:217v. This did not exhaust his Ethiophilia: see his Elogia, 355-6.

73 Subrahmanyam, "World Historians," 26-57.

74 Giovio, Historiarum, 1:216r.

75 Furey, Erasmus, 13.

76 See also Daniels and Anglin, "Luther and the Ethiopian Deacon"
77 Gleason, Contarini, 151; and Salvadore, "African Cosmopolitanism," 72.

78 Ott. Lat. 2789, f. 1, BAV. See also Álvares, Historia; and Natta, "Enigma," esp. 302-3.

79 Ott. Lat. 2789, f. 113r-116v, BAV.

80 Natta, "Enigma," 289-4; and Wilkinson, Orientalism, Aramaic, and Kabbalah, 61-68.

81 Ott. Lat. 2789, f. 113r-115r, BAV.

82 App, Birth of Orientalism, 15-36.

83 Eliav-Feldon, Impostors, 68-96.

84 Davis, "Embassy" 211-302; and Salvadore, The African Prester John, 153-75.

85 Beccari, Rerum Aethiopicarum, 10:5-17.

86 Góis, Fides.

87 Erasmus, Ecclesiastes, 105.

88 Álvares's Verdadeira Informaçao, published the same year as Fides, was approved only after substantial cuts and the addition of an appendix in which Ethiopian faith was questioned: Aubin, "Prêtre Jean," 186-7.

89 Erasmus repeated Sägga Zä'ab's claim that the Ethiopians had been left to themselves: Erasmus, Ecclesiastes, 105; see also Hirsch, De Gois, 146-221.

90 Paschini, "Cervini."

91 Cf. Hudon, Cervini; and Quaranta, Cervini.

92 Cardinali, "Ritratto."

93 Cardinali, "Ritratto," 1:87.

94 Paschini, "Cervini," 392.

95 The Syriac New Testament was printed in Vienna in 1555, but the evidence points to Cervini as the project's originator and sponsor: Cardinali, "Ritratto," no. 1 , passim.

96 Guglielmo Sirleto to Marcello Cervini, Rome 9 July 1547, Vat. Lat. 6177, f. 313, BAV.

97 Marcello Cervini to Bernardino Maffei, 14 March 1546, Trento, Vat. Lat. 6177, f. 418, BAV.

98 Kennerley, "Ethiopian Christians."

99 Yoḥannes to Täsfa Șeyon, 15 December 1548, Ms. DV 13 f. 253, BCI.

100 Sirleto to Cervini, 5 September 1547, Vat. Lat. 6177 f. 350, BAV. 
101 Petrus Ethyops [Täsfa Șeyon], Testamentum, unpaginated $\mathrm{Ge}^{\prime} \mathrm{ez}$ preface. See also Zuurmond, Testamentum, 225.

102 Barberi, "Libri," 222.

103 The volume was printed in in two rounds, in 1548 and 1549, because of the delay in retrieving the Ge' ez manuscript of the Pauline Letters.

104 Petrus Ethyops [Täsfa Șeyon], Testamentum, unpaginated $\mathrm{Ge}$ 'ez preface and f. 226v; Modus baptizandi, f. ii verso; and Giovio, Historiarum, 1:218r. He also acknowledged the assistance of $a b b a$ Yohannes and his $\mathrm{Ge}^{\text {'ez students }}$ Bernardino Sander and Pietro Paolo Gualtieri. Sander was a copyist from Cremona: Bernardinello, Autografi, 27. Gualtieri was the "protector and lord" of the Santo Stefano community, and the only European (not Cervini, pace Wilkinson, Orientalism, Aramaic, and Kabbalah, 69) then competent in $\mathrm{Ge}^{\mathrm{e}} \mathrm{ez}$, in the estimation of Mariano Vittori: see the 1551 Santo Stefano rule in R.I.IV 2218, 233r, BAV; and Victorius, Chaldeae, unpaginated leaf.

105 Lefevre, "Documenti e notizie" and "Documenti pontifici."

10631 August 1538, Camerale 1, registro 1349, f. 30r, ASR.

10711 December 1541, Camerale 1, registro 1290, f. 40r, ASR.

108 "Ruolo (Rotulo) della Famiglia di Giulio III 1550," Camerale 1, busta 2, fascicolo 13, f. 11r, ASR. This document, which identifies the individuals in the papal family and their allowances, was compiled shortly after the elevation of Julius III, suggesting that Täsfa Șeyon's status as a familiar was reconfirmed by the new pontiff.

1098 May 1548, Camerale 1, registro 1293, f. 173r, ASR.

110 Camerale 1, registro 1293, f. 72-172, ASR. At the time of Paul III, a scudo weighed about $3.3 \mathrm{gr}$ of gold.

111 The disbursement is dated 2 April 1547, Camerale 1, registro 1293, f. 125r, ASR. Cf. Lefevre, "Documenti e notizie," 81 and 90, which mistakenly notes one scudo and translates wäqét as ounce. On this unit, see Pankhurst, "Measures," 59-62.

112 Petrus Ethyops [Täsfa Șeyon], Testamentum, unpaginated $\mathrm{Ge}^{\prime} \mathrm{ez}$ preface.

113 Paschini, "Cervini," 395-7; and Vaccaro-Sofia, "Blado."

114 Vat. Lat. 6178, f. 122r, BAV.

115 EA, 3:601-3; Haberland, "Ludolf"; and Hamilton, Copts and the West, 140-57.

116 Ludolf, Lexicon, Grammatica, Historia, and Commentarius.

117 Bausi, "Editing," 55.

118 Haberland, "Ludolf," 3.

119 Ludolf, Lexicon, 188. See also the entry for qomos on 194, in which Ludolf notes Täsfa Șeyon in the usage proof and adds that the title is "proximi post liqanä kahenat." Elsewhere, Ludolf asserted that malhezo was not Täsfa Seyon's title but a patronymic: Ludolf, Lexicon, 59, with "malhazo."

120 Ludolf, Historia, 3: IV, 4. Täsfa Șeyon also features in Ludolf's discussion of Däbrä Libanos (3: III, 28) and the organisation of the Christian kingdom (1: III, 4.).

121 Ludolf, Historia, 3: III, 4.

122 Ludolf, Commentarius, 18, 82, 294-5, and 297, the last of which includes some of Gorgoryos's corrections of typographic errors in the Testamentum. See also the comment on Täsfa Seyon in Ludolf, Confessio, unpaginated note.

123 Diderot, Encyclopédie, passim, for Horn-related entries, e.g., "Alphabet éthiopien et abyssin," "Galles," "Hawasch," and "Méroé."

124 Marchand, Orientalism, 83, 86.

125 EA, 2:61-2.

126 Dillman, Lexicon, 1.

127 These were the Propaganda Fide edition, printed in Rome in 1907, and the Tipografia Francescana edition, printed in Asmara in 1919: Zuurmond, Testamentum, 235-6.

128 The official account is Heruy Wäldä Śelassé, Dästanna käbbär. See also 
Asfa-Wossen Asserate, King of Kings, 52-61; Marcus, Haile Sellasie, 59-77; and De Lorenzi, Guardians, 94-113.

129 Vedovato, Accordi, 8-11.

130 Hueruy Wäldä Śelassé, Dästanna käbbär, 71-5.

131 Heruy Wäldä Śelassé, Dästanna käbbär, 75. The inscriptions transcribed are the same as those presented in Chaîne, "Santo Stefano," 27-32.

132 Heruy Wäldä Śelassé, Dästanna käbbär, 75.

133 Several years later, Heruy produced a survey of Ethiopian literature that noted the diasporic confession of Șägga Zä'ab, which he described as a hagiography, or gädl: Heruy, Katalog, 19.
134 Täklä Maryam Sämḥaray Sälim, Messe, 2. See also Gäbrä Mika'él Germu's account of the sixteenth-century contacts between Ethiopia and Latin Christendom: "Mäsäḥafä meker," EMML 1467.

135 Täklä Sadeq Mäkwuriya, Yä'ityopya tarik, 59-60.

136 Alämé Ešäté, "Tarik," 115-6.

137 Samuel Asghedom, "Santo Stefano." See also the bilingual publication Däbrä qeddus estifanos, published by the Pontifical Ethiopian College in the 1960s.

138 R.I.IV 2218, 227r-233r, BAV.

139 On this erasure, see Girard, "Faustus Naironus," 263.

140 Keller and Irigoyen-García, Dialectics, "Introduction." 